\title{
A SYSTEMATIC REVIEW ON THE STRATEGIES AND TECHNIQUES FOR DECREASING PRESCRIBING ERRORS
}

\author{
Hadeer E. Barakat* \\ Faculty of Pharmacy, Heliopolis University, Cairo, Egypt. \\ haderehab7785@yahoo.com
}

\section{ABSTRACT}

Prescribing errors can lead to tragic consequences in the modern health care systems. The prescribing process faces many barriers that cause limitations, such as information and communications technology (ICT) shortcomings, high workload, complex polypharmacy,patient factors, lack of standardization, and frequent rotations of inexperienced physicians on the wards. Therefore, several strategies and tools were introduced to face this problem, including computerized physician order entry (CPOE), education and training of the prescribers, and expanding the role of the clinical pharmacist.In this systematic review, we are going to address the studies which discussed the different strategies to minimize the prescribing errors. Also, the outcomes and the limitations of each strategy will be discussed throughout this review.Because of the limitations of the application of each strategy separately, it is concluded that the integration between them can lead to overcoming each technique's drawbacks and enhance the decrease in the prescribing errors.

Keywords: Prescribing errors, Prevention, Strategy, CPOE, Education, Pharmacist intervention.

Corresponding Author:Hadeer E. Barakat

\section{INTRODUCTION:}

Medication errors and adverse drug events represent a tragic problem to modern healthcare systems.Medication errors can be broadly classified as prescribing, dispensing or drug administration errors.Medication errors Injure 1.5 Million people a year in the USA, and drug-related injuries occurring in hospitals alone cost $\$ 3.5$ billion annually. ${ }^{1}$ The degree of severity of medication errors according to the national coordinating council for medication error reporting and prevention can range from minor errors to fatal mistakes that can lead to patient's death. ${ }^{2}$ Accordingly, medication errors are accounted to be the seventh most common cause of death in general. ${ }^{3}$

In this context, prescribing errors could be accounted as the most prevalent type of the medication error. ${ }^{4}$ In general, prescribing errors may be defined as the wrong drug selection for a patient. ${ }^{5}$ These errors involve: prescription omissions or inaccurate allergy information; improper or omitted dose; omitted route of administration; improper or omitted frequency; medication omission; incorrect medication or unspecified medication; duplication; drug/allergy interaction; wrong formulation; potential drug/drug interaction; drug/food interaction; unauthorized drug; incorrect treatment duration; illegible order. ${ }^{6}$

The prescribing process faces many barriers that cause limitations, such as high workload, lack of experience of the prescribers,information and communications technology (ICT) shortcomings, complex polypharmacy. ${ }^{7}$ Therefore, it is necessary to understand the causes that contribute to prescribing errors, in order to be able to address these factors. Fig. 1 summarizes the causes of prescribing errors. ${ }^{8}$ 


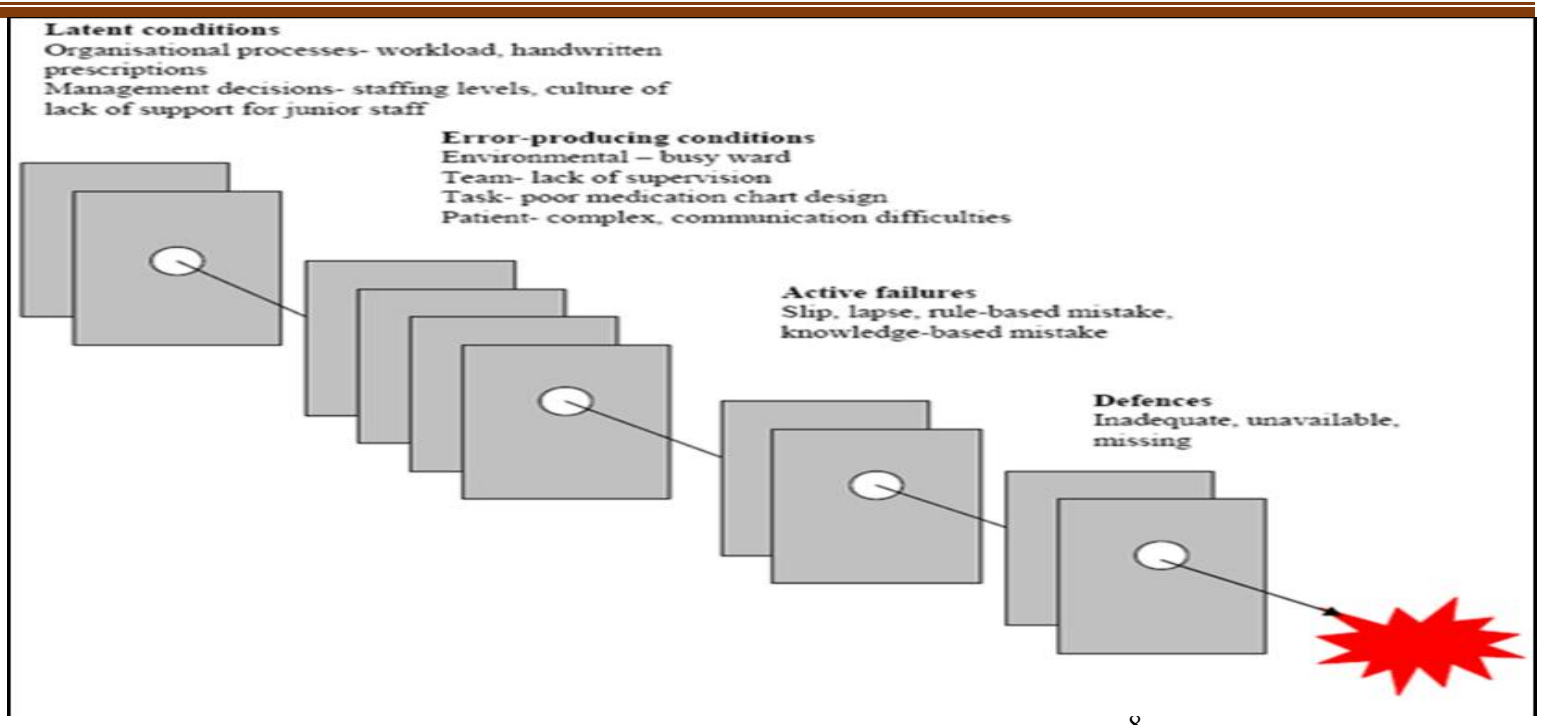

Fig 1. Causes of prescribing errors framework. ${ }^{8}$

In the recent years, different strategies and tools have been introduced inorder to minimize or prevent the prescribing errors. Most studies suggested the introduction of Computerized Physician Order Entry (CPOE) to reduce the prescribing errors, but on the other side, other studies suggested unintended negative consequences of the application of this strategy in preventing the prescribing errors. The second most addressedstrategy is the Educational Initiatives which are intended to prevent the occurrence of prescribing errors especially and the medication errors in general. Education strategies include group training sessions, individual educational visits, letters and printed materials, auditing and error reporting systems, as well as improvement projects.However, some studies concluded that this intervention didn't affect the prescribing error rates and the variation in the programs of training as well as the basic knowledge and education of the prescribers vary between the different studies. The thirdintervention is focused on extending the professional roles, group education sessions, and integration of the clinical pharmacists in the prescribing process for the beneficence of the patients and the prevention of prescribing errors.However, this strategy should be integrated with the other strategies for minimizing the rates of prescribing errors.

Therefore, the main objective of this review article is to address the different strategies (techniques) and tools for minimizing prescribing errors.Furthermore, this review aims to discuss the most powerful strategy for controlling these errors and overcome the limitations of the application of each strategy.

\section{METHODS:}

\section{I- Research methodology}

The Systematic Literature Review(SLR) aims to identify, evaluate, and interpret the literature related to a specific research topic area or question. As the most critical pre-review activity in SLR is to define the Research Questions (RQ) that drive the entire research methodology, in this systematic review, we are going to answer the following questions:

RQ1: What are the strategies and toolsused in minimizing the prescribing errors?

RQ2: What is the study design applied in each study?

RQ3: What are the outcomes of the application of each strategy?

RQ4: Which is the concluded strategy that can lead to almost prescribing errors prevention? 


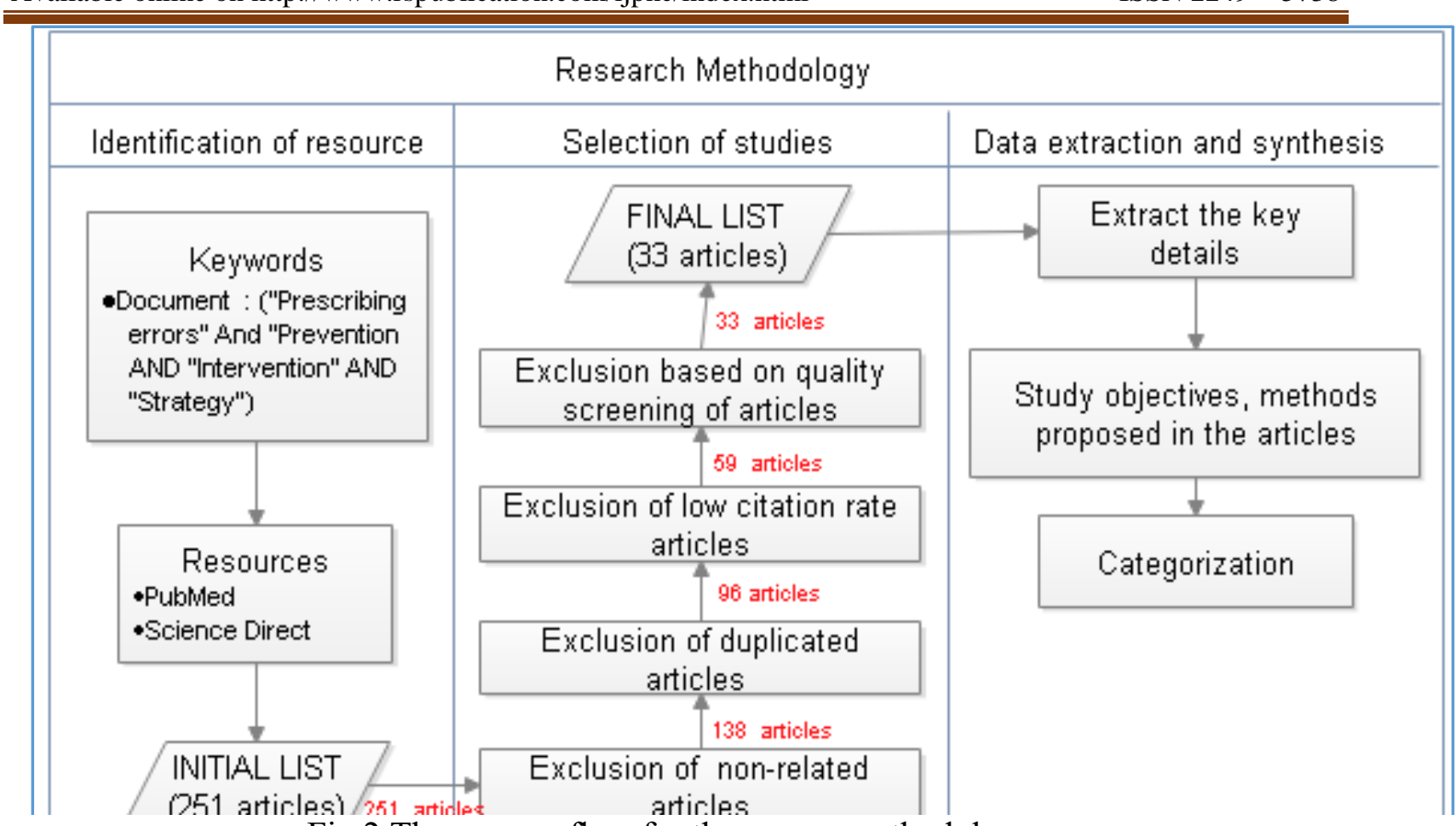

Fig.2 The process flow for the survey methodology.

The stages involved in carrying out SLR are: a) identification of resources, (b) selection of studies, and (c) data extraction and synthesis. First, the identification of resources defines the preliminary searches aimed to assess the volume of potentially relevant studies in the literature resulting in the INITIAL LIST, which contains all the articles matching the search criteria. Then, the main objective of the selection of the studies is to filter the articles in the INITIAL LIST according to several exclusion criteria resulting in the FINAL LIST, which contains all the articles included in our review. Finally, data extractions and synthesis define the extracted data, which were analyzed from each article in the FINAL LIST. Fig. 2 summarizes the process flow for the survey methodology to be discussed in details in the following sections.

\section{II- Identification of resource}

Recognizing the relevant keywords plays a pivotal role in resource identification process. Therefore, an extensive search using (the keywords: "Prescribing error" AND "prevention" AND "intervention" AND "Strategy") as a query text is conducted within the most prominent scientific digital libraries (PubMed and Science Direct). The search is carried out using the following criteria: (1) Articles are published in a reliable peer-reviewed journal or conference; (2) Articles are published between 2000 and 2018; (3) Articles are written in English.

Based on the aforementioned search criteria, a total of 251 articles have been found. These articles are stored in the INITIAL LIST.

\section{III- Selection of studies}

Various ways of selection are suggested in the existing systematic review. In this work, several exclusion criteria are considered and they can be summarized as follows:

- The first rule is to exclude the articles that were not clearly related to the research questions. Articles were only kept for further processing if the contents 
explicitly mention that the main focus of the article is strategies in the prevention of prescribing errors.

- The second rule is to exclude the duplicate articles.

- The remaining articles were subjected to a quality screening such that the articles that did not meet the following quality criteria (QC) are eliminated:

QC1: Is the aim of the research clear?

QC2: Is the proposed strategy feasible?

QC3: Are the results completely analyzed and explained?

QC4: Is the overall quality of the writing good?

QC5: Is the information in the paper sound factual and accurate?

All the articles were examined by answering YES/MAYBE/NO to specify either each criterion was met or not. Then, a score for each article is calculated by giving one point for each "YES" 0.5 points for each "MAYBE" and zero points for each "NO" the article that achieved a score less than 3 points is excluded from the final list used in our review.

Based on our exclusion criteria, 33 articles were selected and stored in the FINAL LIST. All results and discussions provided in this work were extracted from the studies included in the FINAL LIST.

\section{IV- Data extraction and synthesis}

The data extracted from each article in the FINAL LIST were as follows:

- The source (journal and conference) and year of publication.

- Full reference.

- Author's information.

- The study setting.

- The study design.

- The intervention and strategy applied to decrease the prescribing error.

- The outcome of the application of the different strategies on the prescribing error percentage.

- The results and conclusion.

The extracted data was analyzed as per the used terminologies, methods and objectives to categorize the articles in the FINAL LIST. In general, the strategies applied for the prevention of prescribing errors were classified into 3 main strategies: 1) The Computerized Physician Order Entry (CPOE), 2) Education and training of the prescriber, and (3) Pharmacist intervention.

\section{RESULTS AND DISCUSSION:}

In this section, we are going to discuss the studies that addressed each strategy in separate sub-sections, in addition to the study setting, the study design, the intervention (strategy or technique) applied and the outcome of this intervention. Table 1 summarizes the related work addressing the three strategies (CPOE, prescriber education and training, and pharmacist intervention) and their effect on decreasing the prescribing errors.

\section{I- Computerized Physician Order Entry (CPOE):}

The implementation of CPOE in the prescribing process and their impact on minimizing the prescribing errors in the hospital settings is largely discussed in a substantial number of studies in the literature.It was clear that it significantly resulted in improving the prescribing process and the treatment plan. ${ }^{[9-21]}$

These studies addressed different tools in the application of CPOE. For instance, Amato et al reviewed a convenience sample of $10 \mathrm{CPOE}$ systems at 6 sites were evaluated. These 
included both inpatient and outpatient systems, and in-house-developed as well as commercial systems, at academic medical centers, a large managed care organization, and a multispecialty community group practice. In the first phase of the study, the Computerized Prescriber Order Entry Medication Safety (CPOEMS) team assessed the CPOE systems' features and identified problematic issues with medication ordering display and workflow. The second phase of the study involved a review of several different sources of information, including safety and adverse event or error reports, at each of the sites. all available error reports from the 6 sites were collected and reviewed to identify reports of medication errors that occurred in the ordering phase of the medication use process and analyze which errors could be classified as CPOE-related. ${ }^{9}$ Gouyon et al applied the use of neonatal C.P.O.E./C.D.S. system for all prescriptions of all hospitalized newborns over an 18-month period. The preselected prescription of drugs was based on the indication, gestational age, body weight and post-natal age. The therapeutic protocols were provided by a formulary reference (330 drugs) that had been specifically designed for newborns. The preselected prescription also gave complete information about preparation and administration of drugs by nurses. The prescriber was allowed to modify the preselected prescription but alarms provided warning when the prescription was outside the recommended range. The main clinical characteristics and all items of each line of prescription were stored in a data warehouse, thus enabling this study to take place. ${ }^{10}$

Hitti et alcompared the error rates in a randomly selected sample of discharge prescriptions (handwritten versus electronic) five months pre and four months post the introduction of the E-prescription. The internally developed, E-prescription system included a list of 166 commonly prescribed medications with the generic name, strength, dose, frequency and duration. A total of 2,883 prescriptions in this study: 1,475 in the pre-intervention phase were handwritten (HW) and 1,408 in the post-intervention phase were electronic. The rates of 14 different errors were calculated and compared between the pre- and post-intervention period. $^{11}$

On the other hand the CPOE strategy was widely used in the oncology practice especially when prescribing the cytotoxic chemotherapies and the supportive treatment. For example, Elsaid et al reported the development of chemotherapy regimen-specific prescribing templates. Following entry of the patient's data (eg, height, weight, serum creatinine), chemotherapy doses were automatically calculated. Prescribers were able to select the dosing intensity of any chemotherapy drug from a list of pre-specified evidence-based dosing levels. Additionally, a dose adjustment level was preprogrammed into the prescribing module and the adjusted dose was automatically calculated. The prescribing module also contained supportive care instructions as well as administration instructions. Completed chemotherapy prescriptions were automatically sent to the pharmacy for validation and preparation of chemotherapy. ${ }^{15}$

Small et al reported the implementation of commercially available oncology prescribing software in an ambulatory care setting. Prior to implementation of the prescribing software, customization of prescribing templates and menus was performed by specialist oncology pharmacists in the institution. While the oncology prescribing software was equipped with Clinical Decision support (CDS) features including dose calculations, adjustments, and alert generation, the software did not interface with other patient health record systems in the hospital. ${ }^{16}$ Meisenberg et al adopted a quasi-experimental sequential study design to compare handwritten orders, preprinted orders, and CPOE orders over a 5-year period for the frequency of problems or errors in chemotherapy orders. ${ }^{17}$ Harshberger et al evaluated the impact of chemotherapy electronic prescribing using Electronic health record (HER)/CPOE on completeness of regimen documentation for six chemotherapy regimens and clinical staff satisfaction. ${ }^{18}$ 
On the other side, HuertasFernández compared prescription error rates in handwritten versus computerized chemotherapy prescriptions using a concurrent observational study design. ${ }^{19}$ Voeffray et al described the development of a prescribing module directly connected to a standardized chemotherapy regimen database. Upon entry of the patient's data (eg, height, weight, serum creatinine) by the physician, chemotherapy doses were automatically computed. The prescribing module allowed dose modification and required physicians to enter a reason for dose modification. ${ }^{20} \mathrm{Kim}$ et al described their organization's approach to modify a CPOE system to allow prescribing of a complex chemotherapy regimen through programming of pre-specified order sets. These regimen-specific order sets list standardized chemotherapy doses and allow the prescribing of adjunctive supportive care treatments. The CDS features included dose calculations and adjustment based on relevant patient data and clinical laboratory values. ${ }^{21}$

Investigators observed a significant reduction in the probability of order problems and errors when the institution switched to using preprinted order forms from handwritten orders. Additionally, a significant reduction in order problems and errors was observed in CPOEgenerated orders compared with preprinted order sets. The use of CPOE completely eliminated problems and errors related to missing patient identifiers and data, and erroneous dose calculations. ${ }^{[9-21]}$

However, other studies have identified problems related to the involvement of CPOE and clinical decision support (CDS), including the navigation between multiple screens, the confusion of data labels,miss-selection errors, erroneous suggestions of medications and doses. $^{22,23}$ In addition to other errors including, non-intuitive ordering or information transmission, Lack of standardized terminology, interoperability issue, duplicate prescriptions, and repetition of previously corrected errors, reduced visibility of computerized errors. ${ }^{11,22}$ Also, it can lead to a lack of knowledge about the CDS checks that are being performed,inconsistent and insufficient use of CDS to safeguard against errors. ${ }^{[22-25]}$

\section{II- Education strategy:}

The implementation of an educational intervention, is a simple and low-cost strategy that could produce a significant reduction of the prescription error rate. Most studies discussed the educational strategy to cause a significant reduction in prescribing errors.

The percentage of decrease in the errors, as well as the application of educational strategies vary greatly between different studies ${ }^{[26-37]}$ For instance, Rogers et al reviewed adverse drug events (ADEs) reported through a voluntary event reporting system to determine the number and types of immunization errors. During the prescribing phase of the medication-use process, 57\% (43 of 75) of errors occurred. First, age-based restrictions were implemented within the Electronic Medical Record. This was followed by mandatory immunization education for all prescribers working in the primary care network. Data collection included all reported vaccine errors within the voluntary event reporting system and completion rates of education by physicians, nurse practitioners, and medical residents. ${ }^{26}$

Foster et alprovided education on good prescribing/ED medication and prescription errors, followed by daily feedback on patient cases and therapy. ${ }^{27}$ Trivalle et alsuggested education on ADEs and relevant pharmacotherapy in elderly. ${ }^{29}$ Anotherstudy discussed the use of a medication order chart, education on good prescribing and feedback on prescription errors of physicians, provision of dosing assistance. ${ }^{30}$ Martinez-Anton et al,proposed Standardization of prescription sources, update of protocols, education on good prescribing. ${ }^{34}$ on the other hand studies addressed the educational strategy in the ICU department,post cardiac surgery templated physician order, systematic physician education, and in the Emergency Department. ${ }^{[35-37]}$ Thomas et aladdressed the difference between the types of education and compared between online education and high-intensity education. ${ }^{28}$ 
From these studies, it is noted that improvement appears related to an important modification of the behavior of health professionals during drug prescription. On the other side, it should be noted that the initial prescribing error rates vary between different studies.

Although education strategy can enhance the prescribing error percentage $\mathrm{e}^{[26,27 \text { and 29-36] }}$, but some studies revealed that it didn't cause any significant change in prescribing errors. ${ }^{28}$, ${ }^{37}$ Thecontent of the educational programmes and the way of providing the education varied considerably. Different definitions of prescribing errors and ADEs were used, contributing to a large variation in the percentages found. This large variation might also be explained by the difference in the study settings and in the prescribers targeted in the intervention. It has been suggested that the prevention of patient harm is likely to require complex, multifaceted intervention strategies. Education should be embedded in a broader array of measures aimed at appropriate prescribing. Although it is plausible that patients will benefit from educating hospital prescribers in pharmacotherapy, but still further work is needed to develop effective educational interventions and to perform robust evaluations. ${ }^{38}$

The knowledge of how to teach effectively should be combined with optimizing the content of the education. As well, there is no data supporting a specific form of education and training. In addition, studies suggested that educational programmes need a follow-up, to enhance learning retention. Most studies pointed to the importance of combining education with different strategies in a multifaceted intervention to obtain a real improvement in prescription quality. In addition, the qualifications or training of teachers who deliver the educational interventions was rarely addressed in the included studies. This could also have influenced the quality of the intervention and the outcomes.

\section{III- Pharmacist intervention}

Studies of expanding professional roles tend to focus on how pharmacists can identify any error before patients are harmed including checking for errors as prescriptions are received at the pharmacy or in the wards, medicine reconciliation or reviews, in addition to individual or group education sessions.

Most studies suggested that engaging pharmacists in these ways can be beneficial, but few studies have explored the best ways to integrate pharmacists into teams and the interprofessional factors to be considered. ${ }^{[39-46]}$

The intervention of the pharmacist differs between the studies, for example,Kaushal et al addressed full-time pharmacists participation in physician rounds and provided physicians with timely information and advice on ADEs; drug interactions; and appropriate dosages, dose intervals, and routes of administration. ${ }^{39}$ Klopotowska et alreviewed the interventional role of two hospital pharmacistswith 10 years of experience who completed 4 weeks of training in the ICU before the start of this study to guarantee the quality of intervention. ICU hospital pharmacist reviewed medication orders for patients admitted to the ICU, noted issues related to prescribing, formulated recommendations and discussed those issues during patient review meetings with the attending ICU physicians. ${ }^{40}$ Lee et aldiscussed the participation of ICU pharmacist in the collaborative therapeutic management of patients during ICU interdisciplinary medicine rounds, performed chart reviews, and made recommendations. ${ }^{41}$ Ranchon et al and Barakat et al studied the effect of the correlation between some risk factors and the prescribing errors in the oncology department for the prediction of the potential errors and the prevention of their future occurance. ${ }^{41,43}$ Chamoun et al proposed that documentation could be completed by pharmacy students on infectious diseases and cardiology rotations then reviewed by clinical pharmacists with respective specialties. Before data analysis, a new pharmacy reporting sheet was developed in order to link interventions according to medical related problems (MRP). Then, MRPs were grouped into five main medication errors (ME) nodes. Haseeb et alconsidered the pharmacist 
intervention through a series of interactive lectures delivered by an experienced clinical pharmacist to all hospital staff members and dissemination of educational tools (flash cards, printed list of high-risk abbreviations (HRAs), awareness posters) designed in line with the recommendations of the Institute for Safe Medical Practices and the US Food and Drug Administration. ${ }^{46}$

From these studies, we can conclude that the pooled analysis supported the role of pharmacists in reducing preventable ADEs and prescribing errors. Because, these studies show different methods of interventions by the clinical pharmacists to decrease the prescribing errors, in addition to the promising effects of the expansion of the role of the pharmacist in the prescribing process and the pharmacist's interventions due to CPOE for decreasing the prescription errors. But it is clearly obvious that this strategy should be correlated with the previously addressed strategies to achieve minimal prescribing error rates.

Table 1. The related work addressing the three strategies (CPOE, prescriber education and training, and pharmacist intervention) and their effect on decreasing the prescribing errors.

\begin{tabular}{|c|c|c|c|c|}
\hline Study & $\begin{array}{l}\text { Study } \\
\text { setting }\end{array}$ & $\begin{array}{l}\text { Study } \\
\text { design }\end{array}$ & $\begin{array}{c}\text { Type of } \\
\text { intervention } \\
\text { (strategy) }\end{array}$ & Outcome of the intervention \\
\hline $\begin{array}{l}\text { Amato } \\
\text { et al, } \\
2017^{9}\end{array}$ & $\begin{array}{l}6 \text { sites } \\
\text { participating } \\
\text { in a United } \\
\text { States Food } \\
\text { and Drug } \\
\text { Administrati } \\
\text { on }\end{array}$ & Review study & CPOE & $\begin{array}{l}\text { Of } 2522 \text { medication error } \\
\text { reports, } 1308(51.9 \%) \text { were } \\
\text { related to CPOE. Of these, } \\
\text { CPOE facilitated the error in } \\
171(13.1 \%) \text { and potentially } \\
\text { could have prevented } \\
\text { the error in } 1137(86.9 \%) \text {. }\end{array}$ \\
\hline $\begin{array}{l}\text { Gouyon } \\
\text { et al, } \\
2017^{10}\end{array}$ & $\begin{array}{l}29 \text { bed } \\
\text { neonatal } \\
\text { ward }\end{array}$ & Pilot study & CPOE & $\begin{array}{l}\text { About } 30.4 \% \text { of neonates } \\
\text { had at least one out of } \\
\text { licensed prescription; A } \\
\text { prescription out of the } \\
\text { recommended range for daily } \\
\text { dose was recorded for } 1.0 \% \\
\text { of all drug prescriptions. }\end{array}$ \\
\hline $\begin{array}{l}\text { Hitti et } \\
\text { al, } \\
2017^{11}\end{array}$ & $\begin{array}{l}\text { ED of the } \\
\text { American } \\
\text { University } \\
\text { of Beirut } \\
\text { Medical } \\
\text { Center }\end{array}$ & $\begin{array}{l}\text { pre- and post- } \\
\text { intervention study }\end{array}$ & CPOE & $\begin{array}{l}\text { E-prescriptions reduced } \\
\text { missing dose (11.3\% to } \\
4.3 \%) \text { missing frequency } \\
(3.5 \% \text { to } 2.2 \%) \text { missing } \\
\text { strength errors (32.4\% to } \\
10.2 \%) \text { and legibility }(0.7 \% \\
\text { to } 0.2 \%) \text {. E-prescriptions, } \\
\text { however, were associated } \\
\text { with a significant increase in } \\
\text { duplication errors, } \\
\text { specifically with home } \\
\text { medication }(1.7 \% \text { to } 3 \%) \text {. }\end{array}$ \\
\hline $\begin{array}{l}\text { Aziz et } \\
\text { al, } \\
2015^{12}\end{array}$ & $\begin{array}{l}\text { 30-bed } \\
\text { chemothera } \\
\text { py bay of a } \\
\text { tertiary }\end{array}$ & $\begin{array}{l}\text { A prospective } \\
\text { study }\end{array}$ & CPOE & $\begin{array}{l}\text { The incidence of medication } \\
\text { errors was significantly } \\
\text { lower in the Computerized } \\
\text { physician order entry of }\end{array}$ \\
\hline
\end{tabular}




\begin{tabular}{|c|c|c|c|c|}
\hline & hospital. & & & $\begin{array}{l}\text { chemotherapy } \\
\text { compared with the } \begin{array}{r}\text { order } \\
\text { paper- } \\
\text { chemotherapy }\end{array} \\
(10 / 3765[0.26 \%] \text { versus } \\
134 / 5514[2.4 \%]) .\end{array}$ \\
\hline $\begin{array}{l}\text { M. } \\
\text { Sanchez } \\
\text { et al, } \\
2015^{13}\end{array}$ & $\begin{array}{l}\text { Pharmacy } \\
\text { Department } \\
\text { of the } \\
\text { Hospital } \\
\text { Ramon y } \\
\text { Cajal } \\
\text { (Madrid, } \\
\text { Spain) }\end{array}$ & $\begin{array}{l}\text { prospective } \\
\text { analytical study }\end{array}$ & CPOE & 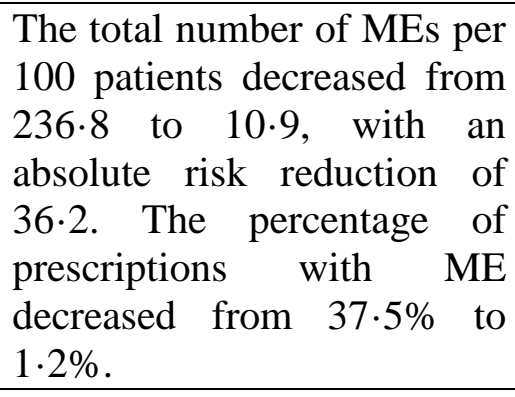 \\
\hline $\begin{array}{l}\text { Colins et } \\
\text { al, } \\
2010^{14}\end{array}$ & $\begin{array}{l}\text { 719-bed } \\
\text { multidiscipli } \\
\text { nary tertiary } \\
\text { care } \\
\text { institution } \\
\text { with a } \\
\text { pediatric } \\
\text { division and } \\
\text { an } \\
\text { outpatient } \\
\text { cancer } \\
\text { center }\end{array}$ & $\begin{array}{l}\text { Pre- and post- } \\
\text { cohort study }\end{array}$ & CPOE & \begin{tabular}{lrr} 
CPOE & implementation \\
significantly & \multicolumn{2}{r}{ reduced } \\
prescribing & error & risk by \\
$69 \%$. & &
\end{tabular} \\
\hline $\begin{array}{l}\text { Elsaid et } \\
\text { al, } \\
2013^{15}\end{array}$ & $\begin{array}{l}\text { 700-bed } \\
\text { multidiscipli } \\
\text { nary tertiary } \\
\text { care hospital } \\
\text { with an } \\
\text { ambulatory } \\
\text { cancer } \\
\text { center }\end{array}$ & $\begin{array}{l}\text { A quasi- } \\
\text { experimental }\end{array}$ & $\mathrm{CPOE}$ & $\begin{array}{l}30 \% \text { reduction in prescribing } \\
\text { errors was observed with } \\
\text { initiating the intervention. }\end{array}$ \\
\hline $\begin{array}{l}\text { Small et } \\
\text { al, } \\
2008^{16}\end{array}$ & $\begin{array}{l}\text { Ambulatory } \\
\text { setting in } \\
\text { the UK }\end{array}$ & Prospective study & $\mathrm{CPOE}$ & $\begin{array}{l}\text { Computerized prescribing } \\
\text { reduced errors by } 42 \% \text {. } \\
\text { Errors occurred in } 20 \% \text { of } \\
\text { spreadsheet prescriptions } \\
\text { compared with } 12 \% \text { of the } \\
\text { computerized prescriptions. }\end{array}$ \\
\hline $\begin{array}{l}\text { Meisenb } \\
\text { erg et al, } \\
2013^{17}\end{array}$ & $\begin{array}{l}\text { Period } \\
\text { Mixed } \\
\text { ambulatory } \\
\text { patients and } \\
\text { inpatients in } \\
\text { the USA }\end{array}$ & $\begin{array}{l}\text { Quasi- } \\
\text { experimental }\end{array}$ & $\mathrm{CPOE}$ & $\begin{array}{l}\text { Reduction from } 30.6 \% \text { with } \\
\text { handwritten orders to } 12.6 \% \\
\text { with preprinted orders to } \\
2.2 \% \text { with CPOE. The } \\
\text { incidence of errors capable } \\
\text { of causing harm was reduced } \\
\text { from } 4.2 \% \text { with handwritten } \\
\text { orders to } 1.5 \% \text { with } \\
\text { preprinted orders to } 0.1 \% \\
\text { with CPOE. }\end{array}$ \\
\hline
\end{tabular}




\begin{tabular}{|c|c|c|c|c|}
\hline $\begin{array}{l}\text { Harshbe } \\
\text { rger et } \\
\text { al, } \\
2011^{18}\end{array}$ & $\begin{array}{l}\text { Mixed } \\
\text { ambulatory } \\
\text { and } \\
\text { inpatient } \\
\text { setting in } \\
\text { the USA }\end{array}$ & $\begin{array}{l}\text { A retrospective } \\
\text { chart review }\end{array}$ & CPOE & $\begin{array}{l}\text { The mean percentage of } \\
\text { identified data points } \\
\text { successfully found in the } \\
\text { Electronic health records } \\
\text { (EHR)/CPOE charts was } \\
93 \% \text { versus } 67 \% \text { in the paper } \\
\text { charts. }\end{array}$ \\
\hline $\begin{array}{l}\text { Huertas } \\
\text { Fernánd } \\
\text { ez et al, } \\
2006^{19}\end{array}$ & $\begin{array}{l}\text { Inpatient } \\
\text { setting in } \\
\text { Spain }\end{array}$ & $\begin{array}{l}\text { A prospective } \\
\text { analysis }\end{array}$ & CPOE & $\begin{array}{l}\text { At least one error was } \\
\text { detected in } 100 \% \text { of the } \\
\text { manual prescriptions and in } \\
13 \% \text { of computerized } \\
\text { prescriptions. The median of } \\
\text { errors per } \\
\text { computerizedprescription } \\
\text { was } 0 \text { (range: } 0-1 \text { ), whereas } \\
\text { in manual prescriptions the } \\
\text { median was } 5 \text { (range: } 1-12 \text { ). }\end{array}$ \\
\hline $\begin{array}{l}\text { Voeffra } \\
\text { y et al, } \\
2006^{20}\end{array}$ & $\begin{array}{l}\text { 850-bed } \\
\text { University } \\
\text { Hospital, } \\
\text { Lausanne, } \\
\text { Switzerland }\end{array}$ & $\begin{array}{l}\text { Observational pre } \\
\text { and post } \\
\text { computational } \\
\text { program }\end{array}$ & $\mathrm{CPOE}$ & $\begin{array}{l}\text { Before computerization, } 141 \\
\text { errors were recorded for } 940 \\
\text { prescribed chemotherapy } \\
\text { regimens }(15 \%) \text {. After the } \\
\text { introduction of the CPOE } \\
\text { system, } 75 \text { errors were } \\
\text { recorded for } 1505 \text { prescribed } \\
\text { chemotherapy regimens } \\
(5 \%) \text { Of these errors, } 69 \\
(92 \%) \text { were recorded in } \\
\text { prescriptions that did not use } \\
\text { a computerized protocol. A } \\
\text { dramatic decrease in the } \\
\text { number of errors was } \\
\text { noticeable when } 50 \% \text { of the } \\
\text { chemotherapy protocols were } \\
\text { prescribed through the CPOE } \\
\text { system. }\end{array}$ \\
\hline $\begin{array}{l}\text { George } \\
\text { R. } \\
\text { Kim,200 } \\
6^{21}\end{array}$ & $\begin{array}{l}\text { Pediatric } \\
\text { Oncology of } \\
\text { the Johns } \\
\text { Hopkins } \\
\text { Children's } \\
\text { Center/Sidn } \\
\text { ey (Kimmel } \\
\text { Comprehens } \\
\text { ive Cancer } \\
\text { Center) }\end{array}$ & $\begin{array}{l}\text { Pre and post the } \\
\text { intervention }\end{array}$ & $\mathrm{CPOE}$ & $\begin{array}{l}\text { After CPOE deployment, a } \\
\text { significant decrease in the } \\
\text { following errors: improper } \\
\text { dosing, incorrect dosing } \\
\text { calculations, missing } \\
\text { cumulative dose calculations, } \\
\text { There was no difference in } \\
\text { the likelihood of improper } \\
\text { dosing on treatment plans } \\
\text { and a higher likelihood of } \\
\text { not matching medication } \\
\text { orders to treatment plans. }\end{array}$ \\
\hline $\begin{array}{l}\text { Rogers, } \\
2016^{26}\end{array}$ & $\begin{array}{l}\text { academic } \\
\text { pediatric } \\
\text { hospital }\end{array}$ & $\begin{array}{l}\text { pre-post } \\
\text { intervention }\end{array}$ & $\begin{array}{l}\text { Education } \\
\text { and training } \\
\text { of the }\end{array}$ & $\begin{array}{l}\text { Prescribing events decreased } \\
\text { from } 57 \% \text { to } 25 \% \text {. Following } \\
\text { implementation of age- }\end{array}$ \\
\hline
\end{tabular}




\begin{tabular}{|c|c|c|c|c|}
\hline & year & & prescriber. & $\begin{array}{l}\text { specific immunization alerts } \\
\text { and mandatory prescriber } \\
\text { education, the hospital went } \\
175 \text { days without a vaccine } \\
\text { ADEs. }\end{array}$ \\
\hline $\begin{array}{l}\text { Foster et } \\
\text { al, } \\
2013^{27}\end{array}$ & $\begin{array}{l}\text { Paediatric } \\
\text { Emergency } \\
\text { Department } \\
\text { (ED), USA }\end{array}$ & $\begin{array}{l}\text { Pre-post } \\
\text { intervention study }\end{array}$ & $\begin{array}{l}\text { Education } \\
\text { and training } \\
\text { of the } \\
\text { prescriber }\end{array}$ & $\begin{array}{l}\text { Significant decrease in dose } \\
\text { adjustments and order } \\
\text { clarifications. }\end{array}$ \\
\hline $\begin{array}{l}\text { Thomas } \\
\text { et al, } \\
2015^{28}\end{array}$ & $\begin{array}{l}\text { Acute } \\
\text { medical } \\
\text { unit, in } 3 \\
\text { hospitals }\end{array}$ & $\begin{array}{l}\text { Controlled pre- } \\
\text { post intervention } \\
\text { study }\end{array}$ & $\begin{array}{l}\text { Education } \\
\text { and training } \\
\text { of the } \\
\text { prescriber }\end{array}$ & $\begin{array}{l}\text { Decrease in some specific } \\
\text { prescribing error rates, no } \\
\text { difference in low- and } \\
\text { high-intensity education. }\end{array}$ \\
\hline $\begin{array}{l}\text { Trivalle } \\
\text { et al, } \\
2010^{29}\end{array}$ & $\begin{array}{l}\text { Geriatric } \\
\text { center, } \\
\text { public } \\
576 \text { elderly } \\
\text { patients }\end{array}$ & $\begin{array}{l}\text { Randomized } \\
\text { prospective study }\end{array}$ & $\begin{array}{l}\text { Education } \\
\text { and training } \\
\text { of the } \\
\text { prescriber. }\end{array}$ & $\begin{array}{lr}\begin{array}{l}\text { Decrease in } \\
\text { intervention }\end{array} & \text { ADEs in } \\
(22 \% \text { vs. } 36 \%) & \end{array}$ \\
\hline $\begin{array}{l}\text { Alagha e } \\
\mathrm{t} \text { al. } \\
2011^{30}\end{array}$ & $\begin{array}{l}139 \\
\text { Paediatric } \\
\text { ICU, Egypt }\end{array}$ & $\begin{array}{l}\text { Pre-post } \\
\text { intervention study }\end{array}$ & $\begin{array}{l}\text { Education } \\
\text { and training } \\
\text { of the } \\
\text { prescriber. }\end{array}$ & $\begin{array}{l}\text { Significant reduction } \\
\text { prescribing } \text { in } \\
(35.2 \% \text { vs. } 78.1 \%)\end{array}$ \\
\hline $\begin{array}{l}\text { Lacomb } \\
\text { e et al, } \\
2005^{31}\end{array}$ & $\begin{array}{l}\text { University } \\
\text { hospital, } \\
\text { France }\end{array}$ & $\begin{array}{lr}\text { Pre-post } & \\
\text { intervention study. } \\
75 \text { patients } \\
\text { intervention, } \\
\text { patients } & 52 \\
\text { intervention } & \text { post- } \\
\end{array}$ & $\begin{array}{l}\text { Education } \\
\text { and training } \\
\text { of the } \\
\text { prescriber }\end{array}$ & $\begin{array}{l}\text { Decrease in prescribing } \\
\text { errors post intervention vs } \\
\text { pre intervention }(60.8 \% \text { vs. } \\
30.8 \%)\end{array}$ \\
\hline $\begin{array}{l}\text { Campin } \\
\text { o et al, } \\
2009^{32}\end{array}$ & $\begin{array}{l}\text { Neonatal } \\
\text { ICU, Spain }\end{array}$ & $\begin{array}{l}\text { Pre-post } \\
\text { intervention study, } \\
4182 \text { prescriptions } \\
\text { pre-intervention, } \\
1512 \text { prescriptions } \\
\text { post intervention }\end{array}$ & $\begin{array}{l}\text { Education } \\
\text { and training } \\
\text { of the } \\
\text { prescriber. }\end{array}$ & \begin{tabular}{lcr} 
Significant & \multicolumn{2}{c}{ reduction } \\
prescribing & error & rate \\
intervention & vs & pre \\
intervention & \multicolumn{2}{c}{$(20.7 \%$ vs. } \\
intervention & \multicolumn{2}{l}{} \\
$3.0 \%)$. & &
\end{tabular} \\
\hline $\begin{array}{l}\text { Rajaman } \\
\text { i et al, } \\
2011^{33}\end{array}$ & $\begin{array}{l}\text { General } \\
\text { ICU, } \\
\text { Australia }\end{array}$ & $\begin{array}{lr}\text { Pre-post } & \\
\text { intervention study, } \\
54 \text { patients } & \text { pre- } \\
\text { intervention, } & 58 \\
\text { patients } & \text { post- } \\
\text { intervention } & \end{array}$ & $\begin{array}{l}\text { Education } \\
\text { and training } \\
\text { of the } \\
\text { prescriber. }\end{array}$ & $\begin{array}{l}\text { There was a highly } \\
\text { significant improvement in } \\
\text { many error rates - illegible } \\
\text { prescriptions reduced from } \\
39.4 \% \text { to } 13.4 \% \text {; absent or } \\
\text { illegible prescriber name } \\
\text { from } 38.3 \% \text { to } 27.0 \% \text {; not } \\
\text { documenting antibiotic } \\
\text { indication from } 64.8 \% \text { to } \\
32.5 \% \text {. }\end{array}$ \\
\hline $\begin{array}{l}\text { Martine } \\
\text { z-Anton } \\
\text { et al, } \\
2012^{34}\end{array}$ & $\begin{array}{l}\text { Pediatric } \\
\text { ICU, Spain }\end{array}$ & $\begin{array}{l}\text { Pre-post } \\
\text { intervention study, } \\
2228 \text { prescriptions } \\
\text { pre-intervention, } \\
1791 \text { prescriptions } \\
\end{array}$ & $\begin{array}{l}\text { Education } \\
\text { and training } \\
\text { of the } \\
\text { prescriber. }\end{array}$ & $\begin{array}{l}\text { Decrease in prescribing } \\
\text { errors }(21.7 \% \text { vs. } 34.2 \%) .\end{array}$ \\
\hline
\end{tabular}




\begin{tabular}{|c|c|c|c|c|}
\hline & & post-intervention & & \\
\hline $\begin{array}{l}\text { Thomas } \\
\text { et al, } \\
2008^{35}\end{array}$ & $\begin{array}{l}\text { ICU, UK } \\
\text { pre- } \\
\text { intervention, }\end{array}$ & $\begin{array}{l}\text { Pre-post } \\
\text { intervention study, } \\
373 \text { prescriptions } \\
974 \text { and } 1022 \\
\text { prescriptions post- } \\
\text { intervention }\end{array}$ & $\begin{array}{l}\text { Education } \\
\text { and training } \\
\text { of the } \\
\text { prescriber. }\end{array}$ & $\begin{array}{l}\text { Showed no change in the } \\
\text { first month after the } \\
\text { intervention. } \\
\text { Later reported a significant } \\
\text { decrease in prescribing error } \\
\text { rates after an education } \\
\text { intervention }\end{array}$ \\
\hline $\begin{array}{l}\text { Burmest } \\
\text { er et al, } \\
2008^{36}\end{array}$ & $\begin{array}{l}\text { Pediatric } \\
\text { cardiac } \\
\text { ICU, USA }\end{array}$ & $\begin{array}{l}\text { Pre-post } \\
\text { intervention study } \\
3648 \text { prescriptions } \\
\text { pre-intervention, } \\
8929 \text { prescriptions } \\
\text { post-intervention }\end{array}$ & $\begin{array}{l}\text { Education } \\
\text { and training } \\
\text { of the } \\
\text { prescriber. }\end{array}$ & $\begin{array}{l}\text { Significant reduction in total } \\
\text { prescribing errors }(16.8 \% \text { to } \\
4.8 \%)\end{array}$ \\
\hline $\begin{array}{l}\text { Kozer et } \\
\text { al, } \\
2006^{37}\end{array}$ & $\begin{array}{l}899 \\
\text { prescription } \\
\text { in } \\
\text { thePediatric } \\
\text { emergency } \\
\text { care, } \\
\text { Canada }\end{array}$ & $\begin{array}{l}\text { Prospective } \\
\text { controlled cohort } \\
\text { study }\end{array}$ & $\begin{array}{l}\text { Education } \\
\text { and training } \\
\text { of the } \\
\text { prescriber. }\end{array}$ & $\begin{array}{l}\text { No difference in prescribing } \\
\text { errors between educated and } \\
\text { non-educated residents } \\
(12.4 \% \text { vs. } 12.7 \%)\end{array}$ \\
\hline $\begin{array}{l}\text { Kaushal } \\
\text { et al, } \\
2008^{39}\end{array}$ & $\begin{array}{l}\text { Teaching } \\
\text { hospital; } \\
\text { pediatric } \\
\text { ICU as the } \\
\text { study unit } \\
\text { and a } \\
\text { cardiac ICU } \\
\text { for control } \\
\text { unit }\end{array}$ & $\begin{array}{l}\text { Pre and post } \\
\text { intervention }\end{array}$ & $\begin{array}{l}\text { Pharmacist } \\
\text { intervention. }\end{array}$ & $\begin{array}{l}\text { The baseline rates of serious } \\
\text { medication errors per } 1000 \\
\text { patient days were } 29 \text { for the } \\
\text { ICU, } 8 \text { for the general } \\
\text { medical unit, and } 7 \text { for the } \\
\text { general surgical unit. With } \\
\text { unit-based clinical } \\
\text { pharmacists, the ICU rate } \\
\text { dropped to } 6 \text { per } 1000 \text { patient } \\
\text { days. In the general care } \\
\text { units, there was no reduction } \\
\text { from baseline in the rates of } \\
\text { serious medication errors. A } \\
\text { full-time unit-based clinical } \\
\text { pharmacist substantially } \\
\text { decreased the rate of serious } \\
\text { medication errors in a } \\
\text { pediatric ICU, but a part- } \\
\text { time pharmacist was not as } \\
\text { effective in decreasing errors } \\
\text { in pediatric general care } \\
\text { units. }\end{array}$ \\
\hline $\begin{array}{l}\text { Klopoto } \\
\text { wska et } \\
\text { al, } \\
2010^{40}\end{array}$ & $\begin{array}{l}\text { The } \\
\text { Netherland } \\
\text { ICU, 28-bed } \\
\text { medical and } \\
\text { surgical } \\
\text { ICU in an }\end{array}$ & $\begin{array}{lr}\text { Prospective } & \text { study } \\
\text { compared } & \text { a } \\
\text { baseline } & \text { period } \\
\text { with } & \text { an } \\
\text { intervention } & \\
\text { period. } & \end{array}$ & $\begin{array}{l}\text { Pharmacist } \\
\text { intervention. }\end{array}$ & $\begin{array}{l}\text { The ICU hospital pharmacist } \\
\text { made a total of } 659 \\
\text { recommendations. During } \\
\text { the intervention period, the } \\
\text { rate of consensus between } \\
\text { the ICU hospital pharmacist }\end{array}$ \\
\hline
\end{tabular}




\begin{tabular}{|c|c|c|c|c|}
\hline & $\begin{array}{l}\text { academic } \\
\text { hospital }\end{array}$ & & & $\begin{array}{l}\text { and ICU physicians was } \\
74 \% \text {. The incidence of } \\
\text { prescribing errors during the } \\
\text { intervention period was } \\
\text { significantly lower than } \\
\text { during the baseline period: } \\
62.5 \text { per } 1,000 \text { monitored } \\
\text { patient-days versus } 190.5 \text { per } \\
1,000 \text { monitored patient- } \\
\text { days, respectively. } \\
\text { Preventable ADEs (patient } \\
\text { harm, National Coordinating } \\
\text { Council for Medication Error } \\
\text { Reporting and Prevention } \\
\text { severity categories E and F) } \\
\text { were reduced from } 4.0 \text { per } \\
1,000 \text { monitored patient-days } \\
\text { during the baseline period to } \\
1.0 \text { per 1,000 monitored } \\
\text { patient-days during the } \\
\text { intervention period. Per } \\
\text { monitored patient-day, the } \\
\text { intervention itself cost } € 3 \text {, } \\
\text { but might have saved } € 26 \text { to } \\
€ 40 \text { by preventing ADEs. }\end{array}$ \\
\hline $\begin{array}{l}\text { F. } \\
\text { Ranchon } \\
\text { et al, } \\
2012^{41}\end{array}$ & $\begin{array}{l}\text { 1200-bed } \\
\text { university } \\
\text { hospital }\end{array}$ & $\begin{array}{l}\text { cross-sectional } \\
\text { observational } \\
\text { study }\end{array}$ & $\begin{array}{l}\text { Pharmacist } \\
\text { intervention. }\end{array}$ & $\begin{array}{l}\text { The independent risk factors } \\
\text { identified should be targeted } \\
\text { for preventive measures in } \\
\text { order to improve anticancer } \\
\text { agent prescriptions and } \\
\text { reduce the risk of medication } \\
\text { errors. }\end{array}$ \\
\hline $\begin{array}{l}\text { Lee et } \\
\text { al, } \\
2007^{42}\end{array}$ & $\begin{array}{l}\text { United } \\
\text { States, 18- } \\
\text { bed } \\
\text { integrated } \\
\text { surgical,me } \\
\text { dical, and } \\
\text { coronary } \\
\text { care,ICU in } \\
\text { a tertiary } \\
\text { care,teachin } \\
\text { g hospital }\end{array}$ & $\begin{array}{l}\text { Historically } \\
\text { controlled study }\end{array}$ & $\begin{array}{l}\text { Pharmacist } \\
\text { intervention. }\end{array}$ & $\begin{array}{l}\text { There was no significant } \\
\text { difference between the } \\
\text { groups for gender and mean } \\
\text { age. Of the } 267 \text { interventions } \\
\text { included in the ICU } \\
\text { pharmacist phase, } 256 \text { were } \\
\text { classified as medication } \\
\text { errors compared with } 54 \text { of } \\
58 \text { interventions for the } \\
\text { control phase. The average } \\
\text { number of medication errors } \\
\text { per day was significantly } \\
\text { higher during the ICU } \\
\text { pharmacist phase ( } 4.27 \pm \\
5.2) \text { compared with the } \\
\text { control phase (0.92 } \pm 1.29) \text {. } \\
\text { The number of medication } \\
\text { errors "averted" was higher }\end{array}$ \\
\hline
\end{tabular}




\begin{tabular}{|c|c|c|c|c|}
\hline & & & & $\begin{array}{l}\text { in the ICU pharmacist phase } \\
\text { compared with the control } \\
\text { phase ( } 212 \text { vs } 50) \text {. The } \\
\text { "averted" medication errors } \\
\text { during the ICU pharmacist } \\
\text { phase were related to a } \\
\text { higher percentage of } \\
\text { improved or resolved clinical } \\
\text { outcomes compared with the } \\
\text { control phase }(66 / 194[34 \%] \\
\text { vs } 7 / 46[15.2 \%]) \text {. }\end{array}$ \\
\hline $\begin{array}{l}\text { Barakat } \\
\text { et al, } \\
2016^{43}\end{array}$ & $\begin{array}{l}500 \\
\text { oncology } \\
\text { out-patients } \\
\text { in the } \\
\text { chemothera } \\
\text { py central } \\
\text { clinic, } \\
\text { Egypt }\end{array}$ & $\begin{array}{l}\text { cross-sectional } \\
\text { observational } \\
\text { study }\end{array}$ & $\begin{array}{l}\text { Pharmacist } \\
\text { intervention }\end{array}$ & $\begin{array}{l}\text { The identification of risk } \\
\text { factors leading to prescribing } \\
\text { errors should be targeted for } \\
\text { significant decrease in the } \\
\text { prescribing errors. }\end{array}$ \\
\hline $\begin{array}{l}\text { Leape et } \\
\text { al, } \\
1999^{44}\end{array}$ & $\begin{array}{l}\text { United } \\
\text { States, 17- } \\
\text { bed medical } \\
\text { ICU as } \\
\text { thestudy } \\
\text { unit and a } \\
\text { 15- } \\
\text { bedcoronary } \\
\text { ICU as the } \\
\text { controlunit }\end{array}$ & $\begin{array}{l}\text { Pre and post } \\
\text { intervention }\end{array}$ & $\begin{array}{l}\text { Pharmacist } \\
\text { intervention. }\end{array}$ & $\begin{array}{l}\text { The rate of preventable } \\
\text { ordering ADEs decreased by } \\
66 \% \text { from } 10.4 \text { per } 1000 \\
\text { patient-days before the } \\
\text { intervention to } 3.5 \text { after the } \\
\text { intervention. In the control } \\
\text { unit, the rate was essentially } \\
\text { unchanged during the same } \\
\text { time periods: } 10.9 \text { and } 12.4 \\
\text { per } 1000 \text { patient-days. The } \\
\text { pharmacist made } 366 \\
\text { recommendations related to } \\
\text { drug ordering, of which } 362 \\
\text { (99\%) were accepted by } \\
\text { physicians. }\end{array}$ \\
\hline $\begin{array}{l}\text { chamou } \\
\mathrm{n} \text { et al, } \\
2016^{45}\end{array}$ & $\begin{array}{l}\text { The } \\
\text { cardiology } \\
\text { and } \\
\text { infectious } \\
\text { diseases } \\
\text { services at a } \\
\text { teaching } \\
\text { hospital } \\
\text { located in } \\
\text { Beirut, } \\
\text { Lebanon }\end{array}$ & $\begin{array}{l}\text { Retrospective } \\
\text { study }\end{array}$ & $\begin{array}{l}\text { Pharmacist } \\
\text { intervention }\end{array}$ & $\begin{array}{l}\text { A total of } \mathrm{n}=1174 \\
\text { interventions } \\
\text { were } \\
\text { documented. } \mathrm{N}=1091 \\
\text { interventions were classified } \\
\text { as MRPs. Interventions were } \\
\text { analyzed per } 1000 \text { patient } \\
\text { days and resulted in } 340 \\
\text { medication related } \\
\text { problem/1000 patient days. } \\
\text { A } 72 \% \text { reduction in MRP } \\
\text { across all ME nodes was } \\
\text { seen. The majority of } \\
\text { interventions were in the } \\
\text { field of cardiology followed } \\
\text { by infectious disease related. } \\
\text { When interventions per ME }\end{array}$ \\
\hline
\end{tabular}




\begin{tabular}{|c|c|c|c|c|}
\hline & & & & $\begin{array}{l}\text { nodes were analyzed, a high } \\
\text { percentage of intervention } \\
\text { acceptance was noted across } \\
\text { all nodes especially } \\
\text { prescribing }(68.30 \%) \\
\text { monitoring }(77.7 \%) \text { and in } \\
\text { documenting } \\
(79.36 \%) \text {. }\end{array}$ \\
\hline $\begin{array}{l}\text { Haseeb } \\
\text { et al, } \\
2016^{46}\end{array}$ & $\begin{array}{l}\text { A public } \\
\text { emergency } \\
\text { hospital in } \\
\text { Mecca, } \\
\text { Saudi } \\
\text { Arabia. }\end{array}$ & $\begin{array}{l}\text { Quasi- } \\
\text { experimental study }\end{array}$ & $\begin{array}{l}\text { Pharmacist } \\
\text { intervention }\end{array}$ & $\begin{array}{l}\text { Reduction in the incidence of } \\
\text { HRAs use from the pre- } \\
\text { intervention to post- } \\
\text { intervention study } \\
\text { period.The five most } \\
\text { common abbreviations } \\
\text { recorded prior to the } \\
\text { interventions were 'IJ for } \\
\text { injection' (28.6\%), 'SC for } \\
\text { subcutaneous' (17.4\%), drug } \\
\text { name and dose running } \\
\text { together (9.7\%), 'OD for } \\
\text { once daily' (5.8\%) and 'D/C } \\
\text { for discharge' (4.3\%). The } \\
\text { incidence of the use of HRAs } \\
\text { was highest in discharge } \\
\text { prescriptions and dispensing } \\
\text { records (72.7\%) followed by } \\
\text { prescriptions from in-patient } \\
\text { wards (47.3\%). After } \\
\text { the intervention, the overall } \\
\text { incidence of HRA was } \\
\text { significantly reduced by } 52 \% \\
\text { (ie, 53.6\% vs } 25.5 \%) \text { In } \\
\text { addition, there was a } \\
\text { statistically significant } \\
\text { reduction in the incidence of } \\
\text { HRAs across all three } \\
\text { settings: the pharmacy } \\
\text { department ( } 72.7 \% \\
39.3 \% \text { ), inpatient settings } \\
\text { (47.3\% vs } 23.3 \% \text { ) and } \\
\text { emergency wards (40.9\% vs } \\
10.7 \%) \text {. }\end{array}$ \\
\hline
\end{tabular}

CPOE: Computerized Physician Order Entry, ED: Emergency Department, ICU: Intensive Care Unit,E-prescriptions: Electronic prescriptions, MEs: Medication Errors,EHR: Electronic Health Record, ADEs: Adverse Drug Events, MRPs: Medication Related Problems, HRA: High Risk Abbreviation

\section{CONCLUSION}

The integration between the three strategies, computation of physician order entry, education and training of the prescribers as well as the pharmacist intervention in the 
prescribing process can lead to enhancement in the prescribing process and minimize the harms reaching the patients. It is obvious in this systematic review that each technique suffers drawbacks and limitations. The coordination and integration between the three interventional strategies tools can overcome each strategy drawbacks when applied separately, and decrease the medication errors occurring in the prescribing stage.

Therefore more studies are required to study the effect of this integration on the prescribing errors and whether this integration could lead to complete prevention of the prescribing error rates in the health care practices.

\section{REFERENCES}

1- Aspden P, Wolcott JA, Bootmann JL, Cronenwett LR. Preventing Medication Errors. Committee on Identifying and Preventing Medication Errors, Institute of Medicine of the National Academies.

2- The National Coordinating Council for Medication Error Reporting and Prevention nccmerp. (2014). Available at: http://www.nccmerp.org/medErrorCatIndex.html .

3- Moyen E, Camiré E, Stelfox HT. Clinical review: medication errors in critical care. Critical Care. 2008 Apr;12(2):208.

4- Alsulami Z, Conroy S, Choonara I. Medication errors in the Middle East countries: a systematic review of the literature. European journal of clinical pharmacology. 2013 Apr 1;69(4):995-1008.

5- Williams DJ. Medication errors. Journal-royal college of physicians of edinburgh. 2007;37(4):343.

6- Bobb A, Gleason K, Husch M, Feinglass J, Yarnold PR, Noskin GA. The epidemiology of prescribing errors: the potential impact of computerized prescriber order entry. Archives of internal medicine. 2004 Apr 12;164(7):785-92.

7- Lewis PJ, Ashcroft DM, Dornan T, Taylor D, Wass V, Tully MP. Exploring the causes of junior doctors' prescribing mistakes: a qualitative study. British journal of clinical pharmacology. 2014 Aug 1;78(2):310-9.

8- Coombes ID, Stowasser DA, Coombes JA, Mitchell C. Why do interns make prescribing errors? A qualitative study. Medical Journal of Australia. 2008 Jan 21;188(2):89.

9- Amato MG, Salazar A, Hickman TT, Quist AJ, Volk LA, Wright A, McEvoy D, Galanter WL, Koppel R, Loudin B, Adelman J. Computerized prescriber order entry-related patient safety reports: analysis of 2522 medication errors. Journal of the American Medical Informatics Association. 2017 Mar 1;24(2):316-22.

10- Gouyon B, Iacobelli S, Saliba E, Quantin C, Pignolet A, Jacqz-Aigrain E, Gouyon JB. A Computer Prescribing Order Entry-Clinical Decision Support system designed for neonatal care: results of the 'preselected prescription'concept at the bedside. Journal of clinical pharmacy and therapeutics. 2017 Feb;42(1):64-8.

11-Hitti E, Tamim H, Bakhti R, Zebian D, Mufarrij A. Impact of internally developed electronic prescription on prescribing errors at discharge from the Emergency Department. Western Journal of Emergency Medicine. 2017 Aug;18(5):943.

12- Aziz MT, Ur-Rehman T, Qureshi S, Bukhari NI. Reduction in chemotherapy order errors with computerised physician order entry and clinical decision support systems. Health Information Management Journal. 2015 Oct;44(3):13-22.

13- Sanchez Cuervo M, RojoSanchis A, Pueyo Lopez C, Gomez de Salazar Lopez de Silanes E, Gramage Caro T, Bermejo Vicedo T. The impact of a computerized physician order entry system on medical errors with antineoplastic drugs 5 years after its implementation. Journal of clinical pharmacy and therapeutics. 2015 Oct;40(5):550-4. 
14- Collins CM, Elsaid KA. Using an enhanced oral chemotherapy computerized provider order entry system to reduce prescribing errors and improve safety. International Journal for Quality in Health Care. 2010 Nov 16;23(1):36-43

15-Elsaid K, Truong T, Monckeberg M, McCarthy H, Butera J, Collins C. Impact of electronic chemotherapy order forms on prescribing errors at an urban medical center: results from an interrupted time-series analysis. International journal for quality in health care. 2013 Oct 16;25(6):656-63.

16- Small M, Barrett A, Price GM. The impact of computerized prescribing on error rate in a department of oncology/hematology. J Oncol Pharm Pract. 2008;14:181-187.

17- Meisenberg BR, Wright RR, Brady-Copertino CJ. Reduction in chemotherapy order errors with computerized physician order entry. Journal of oncology practice. 2013 Sep $3 ; 10(1):$ e5-9.

18- Harshberger CA, Harper AJ, Carro GW, Spath WE, Hui WC, Lawton JM, Brockstein BE. Outcomes of computerized physician order entry in an electronic health record after implementation in an outpatient oncology setting. Journal of oncology practice. 2011 Jul;7(4):233-7.

19- Fernández MJ, Bautista MJ, Arellano EA, Palacios MV. Impact of computerised chemotherapy prescriptions on the prevention of medication errors. Clinical and Translational Oncology. 2006 Nov 1;8(11):821-5.

20- Voeffray M, Pannatier A, Stupp R, Fucina N, Leyvraz S, Wasserfallen JB. Effect of computerisation on the quality and safety of chemotherapy prescription. BMJ Quality \& Safety. 2006 Dec 1;15(6):418-21.

21- Kim GR, Chen AR, Arceci RJ, Mitchell SH, Kokoszka KM, Daniel D, Lehmann CU. Error reduction in pediatric chemotherapy: computerized order entry and failure modes and effects analysis. Archives of pediatrics \& adolescent medicine. 2006 May $1 ; 160(5): 495-8$.

22- Horsky J, Kuperman GJ, Patel VL. Comprehensive analysis of a medication dosing error related to CPOE. Journal of the American Medical Informatics Association. 2005 Jul $1 ; 12(4): 377-82$.

23- Adelman JS, Kalkut GE, Schechter CB, Weiss JM, Berger MA, Reissman SH, Cohen HW, Lorenzen SJ, Burack DA, Southern WN. Understanding and preventing wrongpatient electronic orders: a randomized controlled trial. Journal of the American Medical Informatics Association. 2012 Jun 29;20(2):305-10.

24- Schiff GD, Amato MG, Eguale T, Boehne JJ, Wright A, Koppel R, Rashidee AH, Elson RB, Whitney DL, Thach TT, Bates DW. Computerised physician order entry-related medication errors: analysis of reported errors and vulnerability testing of current systems. BMJ QualSaf. 2015 Apr 1;24(4):264-71.

25- Khajouei R, Wierenga PC, Hasman A, Jaspers MW. Clinicians satisfaction with CPOE ease of use and effect on clinicians' workflow, efficiency and medication safety. International journal of medical informatics. 2011 May 1;80(5):297-309.

26- Rogers J, Sebastian S, Cotton W, Pippin C, Merandi J. Reduction of immunization errors through practitioner education and addition of age-specific alerts in the electronic prescribing system. American Journal of Health-System Pharmacy. 2016 Jun 1;73(11 Supplement 3):S74-9.

27- Foster ME, Lighter DE, Godambe AV, Edgerson B, Bradley R, Godambe S. Effect of a resident physician educational program on pediatric emergency department pharmacy interventions and medication errors. The Journal of Pediatric Pharmacology and Therapeutics. 2013 Jan;18(1):53-62. 
28- Thomas JS, Gillard D, Khor M, Hakendorf P, Thompson CH. A comparison of educational interventions to improve prescribing by junior doctors. QJM: An International Journal of Medicine. 2014 Oct 16;108(5):369-77.

29- Trivalle C, Cartier T, Verny C, Mathieu AM, Davrinche P, Agostini H, Becquemont L, Demolis P. Identifying and preventing adverse drug events in elderly hospitalised patients: a randomised trial of a program to reduce adverse drug effects. The journal of nutrition, health \& aging. 2010 Jan 1;14(1):57-61.

30- Alagha HZ, Badary OA, Ibrahim HM, Sabri NA. Reducing prescribing errors in the paediatric intensive care unit: an experience from Egypt. ActaPaediatrica. 2011 Oct;100(10):e169-74.

31- Lacombe K, Cariou S, Tilleul P, Offenstadt G, Meynard JL. Optimizing fluoroquinolone utilization in a public hospital: a prospective study of educational intervention. European Journal of Clinical Microbiology and Infectious Diseases. 2005 Jan 1;24(1):6-11.

32-Campino A, Lopez-Herrera MC, Lopez-de-Heredia I, Valls-i-Soler A. Educational strategy to reduce medication errors in a neonatal intensive care unit. ActaPaediatrica. 2009 May 1;98(5):782-5.

33-Rajamani A, Suen S, Phillips D, Thomson M. The SCRIPT project: a knowledge translation approach to improve prescription practice in a general intensive care unit. Critical Care and Resuscitation. 2011 Dec;13(4):245.

34- Martinez-Anton A, Sanchez JI, Casanueva L. Impact of an intervention to reduce prescribing errors in a pediatric intensive care unit. Intensive care medicine. 2012 Sep $1 ; 38(9): 1532-8$.

35- Thomas AN, Boxall EM, Laha SK, Day AJ, Grundy D. An educational and audit tool to reduce prescribing error in intensive care. BMJ Quality \& Safety. 2008 Oct 1;17(5):3603.

36- Burmester MK, Dionne R, Thiagarajan RR, Laussen PC. Interventions to reduce medication prescribing errors in a paediatric cardiac intensive care unit. Intensive care medicine. 2008 Jun 1;34(6):1083-90.

37-Kozer E, Scolnik D, Macpherson A, Rauchwerger D, Koren G. The effect of a short tutorial on the incidence of prescribing errors in pediatric emergency care. Can $\mathbf{J}$ ClinPharmacol. 2006;13(3):e285-91.

38- Bos JM, Bemt PM, Smet PA, Kramers C. The effect of prescriber education on medication-related patient harm in the hospital: a systematic review. British journal of clinical pharmacology. 2017 May 1;83(5):953-61.

39- Kaushal R, Bates DW, Abramson EL, Soukup JR, Goldmann DA. Unit-based clinical pharmacists' prevention of serious medication errors in pediatric inpatients. American Journal of Health-System Pharmacy. 2008 Jul 1;65(13):1254-60.

40- Klopotowska JE, Kuiper R, van Kan HJ, de Pont AC, Dijkgraaf MG, Lie-A-Huen L, Vroom MB, Smorenburg SM. On-ward participation of a hospital pharmacist in a Dutch intensive care unit reduces prescribing errors and related patient harm: an intervention study. Critical Care. 2010 Oct;14(5):R174.

41-Ranchon F, Moch C, You B, Salles G, Schwiertz V, Vantard N, Franchon E, Dussart C, Henin E, Colomban O, Girard P. Predictors of prescription errors involving anticancer chemotherapy agents. European Journal of Cancer. 2012 May 1;48(8):1192-9.

42- Lee AJ, Chiao TB, Lam JT, Khan S, Boro MS. Improving medication safety in the ICU: the pharmacist's role. Hospital Pharmacy. 2007 Apr;42(4):337-44.

43- Barakat HE, Sabri NA, Saad AS. Prediction of chemotherapy prescribing errors for oncology patients. International journal of pharmaceutical sciences and research. 2016 Aug. 1; 7(8):3274-83. 
44- Leape LL, Cullen DJ, Clapp MD, Burdick E, Demonaco HJ, Erickson JI, Bates DW. Pharmacist participation on physician rounds and adverse drug events in the intensive care unit. Jama. 1999 Jul 21;282(3):267-70.

45- Chamoun NR, Zeenny R, Mansour H. Impact of clinical pharmacy interventions on medication error nodes. International journal of clinical pharmacy. 2016 Dec $1 ; 38(6): 1436-44$.

46- Haseeb A, Winit-Watjana W, Bakhsh AR, Elrggal ME, Hadi MA, Mously AA, Gadibalban AZ, Al-Ibraheem BF, Almubark RA, Ekram RA, Khan TM. Effectiveness of a pharmacist-led educational intervention to reduce the use of high-risk abbreviations in an acute care setting in Saudi Arabia: a quasi-experimental study. BMJ open. 2016 Jun 1;6(6):e011401. 